\title{
Evaluation of selected capital market
}

\author{
Jakub Horák ${ }^{1, *}$, Eva Kalinová2, and Andrea Novotná ${ }^{1}$ \\ ${ }^{1}$ Institute of Technology and Business in České Budějovice, School of Expertness and Valuation, \\ Okružní 517/10, 37001 České Budějovice, Czech Republic \\ ${ }^{2}$ University of Žilina, The Faculty of Operation and Economics of Transport and Communications, \\ Department of Economics, Univerzitná 8215/1, 01026 Žilina, Slovakia
}

\begin{abstract}
Research background: Stock exchange trading is an activity carried out in order to achieve a profit. The oldest and largest market operator in the CR is the Prague Stock Exchange. The complex development of the market in a given period with regard to its development trends is monitored by means of the stock market index. The index of the Prague Stock Exchange is PX index.

Purpose of the article: The objective of the contribution is the evaluation of the development of the PX index in the years 2018-2020 and the prediction of its further development.

Methods: The data on the PX index were obtained from the official Prague Stock Exchange websites. The data are available for the period of 26 March 2018-31 March 2021. The processed data are analysed using neural networks, specifically the time series analysis. The opening price is used as a variable.

Findings \& Value added: The research results show that the Czech market index has been relatively stable in the past, its values being around its initial value, 1,000 points. No major fluctuations were recorded, as the PX index included very stable firms. However, with the onset of the COVID-19 pandemic, there was a sharp decline caused by the effect of anti-pandemic measures on the economy. Currently, the Czech market index is expected to grow gradually and stabilize at around 1,000 points.
\end{abstract}

Keywords: PX index; neural networks; capital market; stock exchange

JEL Classification: $C 22$; $C 32$; $C 45$; $C 53$

\footnotetext{
* Corresponding author: horak@mail.vstecb.cz
} 


\section{Introduction}

Prague Stock Exchange is characterised as the largest and oldest securities market operator in the Czech Republic (Šuleř et al., 2020). It fulfils an important and substantial function for the entire economy of the CR. In particular, it is of great importance especially for enterprises whose entry on the stock exchange brings them additional capital they can use for their development, accelerating research or expand their business activities to other markets (Vochozka et al., 2020).

Prague Stock Exchange also plays an important role, because it reacts to the market development and gives signals to the economy about in which industry growth or decrease shall be expected, thus pointing to the areas of future investments (Šuleř et al., 2020). If economic growth is expected, there are purchased securities of enterprises operating in the field where the economic growth is expected, which increases investment possibilities in this field. Conversely, in the case of expected recession, securities of entities operating in the industries where the recession is expected are sold. Trading on the stock market is an activity performed in order to generate profit. The price of the shares is given by the investors' interest. The price is increased by an excess of demand and decreased by an excess of supply. For this reason, investors try to avoid financial loss by selling shares when their price falls (Šuleř et al., 2020).

Given its development trends, the development of market as a whole over time is monitored using the stock market index. The index of Prague Stock Exchange is the PX index, which was first calculated on 20 March 2006, replacing the indexes PX 50 and PX-D. The index took the historical values of PX50, which included 50 enterprises on the Prague Stock Exchange (Reuse and Svoboda, 2017). In contrast, the PX index is based on tradable shares of 13 enterprises. The index has traditional econometric properties of financial time series (Horníková, 2003).

Due to the global COVID-19 pandemic, many stock markets have fallen by more than 40 $\%$; enterprises are shutting down, terminating contracts, and voluntary and involuntary leaves occur. These economic consequences have increased the unemployment rate, crime and instability (Almehmadi, 2021). As a response to the COVID-19 pandemic, stock returns and stock markets have fallen rapidly. The findings also indicate that the negative response of the market was stronger in the early phase of the outbreak of the pandemic, between the $26^{\text {th }}$ and $35^{\text {th }}$ day after the first confirmed cases (Al-Qudah and Houcine, 2021).

The objective of the paper is to evaluate the development of the PX index between 2018 and 2020 and predict its future development. For this purpose, the following research questions have been formulated:

RQ1: How did the PX index evolve in the past before the pandemic?

RQ2: How is the PX index evolving during the COVID-19 pandemic?

RQ3: What is the projected development of the PX index for the year 2021?

\section{Literature research}

Pandemics usually affect the global economy, and the COVID-19 pandemic is no exception (Majerová and Fernandez, 2020). Based on this fact, various studies have been carried out since 2020, which examine the influence of the ongoing pandemic on the day-to-day operation of the economy and its future impacts. One of the studies focused on investigating the effect of the COVID-19 outbreak on the daily stock returns. The results showed the negative impact on the stock returns. In response to the pandemic, stock markets have fallen rapidly (Al-Qudah and Houcine, 2021). A study conducted in India investigates whether the COVID-19 pandemic induces share price volatility. For the analysis, daily closing prices of the Nifty and Sensex shares were used. The findings indicate that the Indian stock market 
experienced volatility in the pandemic period. The study also shows that the returns of indexes were higher before the COVID-19 pandemic compared to the pandemic period (Bora and Basistha, 2021).

The risks between two markets are transmitted faster if their parameters exceed the thresholds (Dias et al., 2020). The results of a study focused on the effect of capital market development and financial development on the economic growth in three West African countries show that the capital market development negatively affects the economic growth both in the short and long run (Appiah et al., 2020). Gubareva and Chondroginnis (2020) argue that the sensitivity of the capital gain between the BBB-rated US bonds and state bonds is weak and positive in the current period, but strong and negative in the period of recession.

An important and positive contribution of the empirical research is an example of how wavelet analysis can be used for examining various reactions of financial markets (Dias et al. 2020). Wavelet analysis can e.g. reveal a trend in financial data (Liua and Yang, 2021). It is a well-known fact that financial markets across all classes of assets exhibit trends which have been used by traders for decades. However, a more detailed analysis of the data shows that those trends tend to revert when they become too strong (Dias et al., 2020). Alshammari et al. (2020) used wavelet analysis to examine the impact of the exchange rate, oil price, and gold price on Kuwaiti stock market. According to the authors, this method is used for testing non-linear causality and decomposing the data at various time frequencies to better understand various investment horizons. The findings confirm the existence of a positive relationship between stock market and exchange rate at all frequencies. In short, the impact of oil price on stock market is indirectly positive, because it determines the movement of exchange rate.

In order to answer the research questions, several methods have been selected, which deal with the given issue. The first one was used in a study that examines the impact of COVID19 on the daily stock returns in six major affected WHO regions. The study uses an event study method and the models of panel data regression to examine the impact of the daily increase in the number of confirmed cases of COVID-19 on the daily stock returns. The results showed the daily increase in the number of confirmed cases of COVID-19 has a negative impact on the daily stock returns and rapid fall of stock markets as a response to the pandemic (Al-Qudah and Houcine, 2021). Another method is Granger causality, which was used in the study examining the relationship of the price and economic activity of stock in 12 member countries of the Organization for Economic Cooperation and Development. The results showed that in the panel setting, stock prices have predictive power for future longterm economic activity (Yilanci et al., 2021).

$\mathrm{Lu}$ et al. (2021) focused on predictive power of three measures implemented in the US stock market using the MIDAS (mixed data sampling). The analysis show that all implemented measures had a significant impact on the future volatility of shares. Another method to answer the research questions is the method of neural networks. This method was used in the study focused on predicting the exchange rate. The study aims to propose a methodology for considering seasonal fluctuations in smoothing time series using artificial neural networks on the example of Euro and Chinese Yuan. Before the experiment was carried out, it seemed there was no reason to include categorical variables in the calculation. However, the results indicated that other variables in the form of the year, month, day of the month and day of the week in which the value was measured brought higher accuracy and order in time series smoothing (Vochozka et al., 2019).

The method of artificial neural networks turned out to be the best method for answering the research questions concerning the development of the PX index. This method was also used by Vochozka et al. (2019), who confirmed the applicability of this method for finding the answers. 


\section{Data and methods}

The data on the PX index are obtained from the official websites of the Prague Stock Exchange (Pse, 2021). The data are available for the period of 16 March 2018-31 March 2021. The data do not include weekends and national holidays, since these are not trading days in stock markets.

The data obtained are evaluated using the TIBCO software Statistica, Version 13.5.0.17. The analysis of the data processed is performed using the method of neural networks, specifically, time series analysis, with opening odds as a variable. The time series is divided into three datasets. $70 \%$ of the input data is contained in the first part of the time series, which is the training dataset. The test dataset contains $15 \%$ of the input data, while the validation dataset contains the remaining $15 \%$. These two datasets are used for the verification of the accuracy of the neural network. For the input time series lag, the value of 1 is selected; the same value is selected for the time lag of the input time series which determines how many steps are predicted in advance. The networks generated are multilayer perceptron networks (MLP). The algorithm for training MPL networks is BFGS, which is used for solving unlimited non-linear optimization problems (Gu and Yamashita, 2021). In the case of MLP network, the minimum number of neurons in the hidden layer is 2 , the maximum is 8 , while the RBF contains between 21 and 30 neurons in the hidden layer. 1000 networks are generated for training, out of which 5 are retained. For the hidden and input layer of the MLP, the following activation functions are selected:

- $\quad$ Identity: $\operatorname{Id}(x)=x$,

- Logistics: $f(t, a, m, n, t)=a \frac{1+m e^{-t / \tau}}{1+n e^{-t / \tau}}$,

- Hyperbolic tangent: $\tanh x=\frac{\sinh (x)}{\cosh (x)^{\prime}}$

- $\quad$ Exponential: $f(x)=a^{x}$,

- $\quad$ Sine: $f(x)=\sin (x)$,

At this point, we will continue with neural networks weight decay. The selected minimum parameter for weight decay (hidden layer) is 00001, maximum is 0001 . The same values are selected for weight decay (output layer) and "training" is selected.

After applying the selected methodology, the following results are presented:

- Analysis of the input data,

- Retained neural networks,

- Weight decay of neural networks,

- Analysis of smoothed time series,

- Graph of smoothed time series development,

- Graph of predictions.

Table 1 presents the basic characteristics of the actual time series. The data concerning the opening odds were obtained from the Prague Stock Exchange websites (Pse, 2021). Those are opening prices from each day the shares were traded.

Table 1. Dataset characteristics.

\begin{tabular}{|c|c|c|}
\hline Samples & Date & PX \\
\hline Minimum (Train) & $43,185.00$ & 738.240 \\
\hline Maximum (Train) & $44,286.00$ & $1,142.950$ \\
\hline Mean (Train) & $43,727.76$ & $1,022.141$ \\
\hline Standard deviation (Train) & 314.93 & 85.687 \\
\hline
\end{tabular}




\begin{tabular}{|c|c|c|}
\hline Minimum (Test) & $43,193.00$ & 690.480 \\
\hline Maximum (Test) & $44,264.00$ & $1,131.670$ \\
\hline Mean (Test) & $43,756.03$ & $1,011.439$ \\
\hline Standard deviation (Test) & 329.51 & 93.070 \\
\hline Minimum (Validation) & $43,196.00$ & 712.160 \\
\hline Maximum (Validation) & $44,279.00$ & $1,140.450$ \\
\hline Mean (Validation) & $43,756.13$ & $1,033.400$ \\
\hline Standard deviation (Validation) & 492.80 & 62.458 \\
\hline Minimum (Overall) & $43,185.00$ & 690.480 \\
\hline Maximum (Overall) & $44,286.00$ & $1,142.950$ \\
\hline Mean (Overall) & $43,736.18$ & $1,022.224$ \\
\hline Standard deviation (Overall) & 318.31 & 86.767 \\
\hline
\end{tabular}

Source: authors (2021)

In accordance with the selected methodology, 1,000 neural networks were generated, out of which five with the best values were retained (see the parameters in Table 2). All retained networks are MLP. This indicates that neural networks with the training algorithm RBF met the performance parameters. For further analysis of the model quality, one or more generated networks shall be selected. The quality of the network(s) is evaluated in individual datasets, i.e. in the test, training and validation datasets. In most cases, there is selected a network model with high values but not significantly different fluctuations within individual datasets. Table 2 below shows that the most suitable networks are RBF 1-27-1 and RBF 1-27-1.

Table 2. Overview of networks (Data_PX).

\begin{tabular}{|c|c|c|c|c|c|c|c|c|}
\hline Index & Net. name & $\begin{array}{c}\text { Training } \\
\text { perf. }\end{array}$ & Test perf. & $\begin{array}{c}\text { Validation } \\
\text { perf. }\end{array}$ & $\begin{array}{c}\text { Training } \\
\text { error }\end{array}$ & Test error & $\begin{array}{c}\text { Validation } \\
\text { error }\end{array}$ & $\begin{array}{c}\text { Training } \\
\text { algorithm }\end{array}$ \\
\hline 1 & RBF 1-27-1 & 0.975028 & 0.975398 & 0.976398 & 180.3620 & 209.0422 & 167.0291 & RBFT \\
\hline 2 & RBF 1-30-1 & 0.970672 & 0.965635 & 0.973225 & 211.3553 & 292.1212 & 189.3500 & RBFT \\
\hline 3 & RBF 1-28-1 & 0.970280 & 0.962229 & 0.970479 & 214.1400 & 326.8421 & 212.9177 & RBFT \\
\hline 4 & RBF 1-22-1 & 0.974951 & 0.973363 & 0.971368 & 180.9063 & 228.8253 & 201.9295 & RBFT \\
\hline 5 & RBF 1-27-1 & 0.982700 & 0.980577 & 0.977923 & 125.4783 & 165.6565 & 155.6646 & RBFT \\
\hline
\end{tabular}

Source: authors (2021)

Table 3 presents the connections between nodes and the individual assigned weights for all five networks. The networks consist of three layers. The input layer corresponds to the volume of the input information. The continuous variable is time; the input layer thus contains one neuron. The output layer is the PX index, i.e. one continuous number. The output layer thus also contains one neuron. Table 3 below shows the inner structure of the neural network. The complete table is presented in Appendix.

Table 3. Network weights (Data_PX).

\begin{tabular}{|c|c|c|c|c|c|c|c|c|c|c|}
\hline $\begin{array}{l}\text { Weigh } \\
\text { t ID }\end{array}$ & $\begin{array}{c}\text { Connection } \\
\mathrm{s}\end{array}$ & $\begin{array}{l}\text { Weight } \\
\text { values }\end{array}$ & Connections & $\begin{array}{l}\text { Weight } \\
\text { values }\end{array}$ & Connections & $\begin{array}{l}\text { Weight } \\
\text { values }\end{array}$ & Connections & $\begin{array}{l}\text { Weight } \\
\text { values }\end{array}$ & Connections & Weight values \\
\hline 1 & $\begin{array}{c}\text { Date-1 } \rightarrow \\
\text { hidden } \\
\text { neuron } 1\end{array}$ & 0.2770 & $\begin{array}{c}\text { Date-1 } \rightarrow \\
\text { hidden } \\
\text { neuron } 1\end{array}$ & 0.65849 & $\begin{array}{c}\text { Date-1 } \rightarrow \\
\text { hidden neuron } 1\end{array}$ & $\begin{array}{c}0.52316 \\
1\end{array}$ & $\begin{array}{c}\text { Date-1 } \rightarrow \\
\text { hidden neuron } \\
1\end{array}$ & $\begin{array}{c}0.26067 \\
2\end{array}$ & Date- $1 \rightarrow$ hidden neuron 1 & 0.854678 \\
\hline 2 & $\begin{array}{l}\text { Date-1 } \rightarrow \\
\text { hidden } \\
\text { neuron 2 }\end{array}$ & 0.0199 & $\begin{array}{c}\text { Date-1 } \rightarrow \\
\text { hidden } \\
\text { neuron 2 }\end{array}$ & 0.10354 & $\begin{array}{c}\text { Date-1 } \rightarrow \\
\text { hidden neuron } 2\end{array}$ & $\begin{array}{c}0.17983 \\
7\end{array}$ & $\begin{array}{c}\text { Date-1 } \rightarrow \\
\text { hidden neuron } \\
2\end{array}$ & $\begin{array}{c}0.33151 \\
7\end{array}$ & Date- $1 \rightarrow$ hidden neuron 2 & 0.453224 \\
\hline 3 & $\begin{array}{c}\text { Date-1 } \rightarrow \\
\text { hidden } \\
\text { neuron 3 }\end{array}$ & 0.0635 & $\begin{array}{c}\text { Date-1 } \rightarrow \\
\text { hidden } \\
\text { neuron } 3 \\
\end{array}$ & 0.89373 & $\begin{array}{c}\text { Date-1 } \rightarrow \\
\text { hidden neuron } 3\end{array}$ & $\begin{array}{c}0.54132 \\
6\end{array}$ & $\begin{array}{c}\text { Date-1 } \rightarrow \\
\text { hidden neuron } \\
3 \\
\end{array}$ & $\begin{array}{c}0.60399 \\
6\end{array}$ & Date- $1 \rightarrow$ hidden neuron 3 & 0.655767 \\
\hline$\ldots$ & $\ldots$ & $\ldots$ & $\ldots$ & $\ldots$ & $\ldots$ & $\ldots$ & $\ldots$ & $\ldots$ & $\ldots$ & $\ldots$ \\
\hline 80 & $\begin{array}{c}\text { hidden } \\
\text { neuron } 26 \\
\rightarrow \text { Opening } \\
\text { odds }\end{array}$ & 0.0012 & $\begin{array}{c}\text { hidden } \\
\text { neuron } 20 \rightarrow \\
\text { Opening } \\
\text { odds }\end{array}$ & $\begin{array}{c}- \\
0.00000 \\
9\end{array}$ & $\begin{array}{c}\text { hidden neuron } \\
24 \rightarrow \text { Opening } \\
\text { odds }\end{array}$ & $\begin{array}{c}- \\
0.00161 \\
6\end{array}$ & & & $\begin{array}{c}\text { hidden neuron } 26 \text {--> } \\
\text { Opening odds }\end{array}$ & -0.004146 \\
\hline
\end{tabular}




\begin{tabular}{|c|c|c|c|c|c|c|c|c|c|}
\hline 81 & $\begin{array}{c}\text { hidden } \\
\text { neuron 27- } \\
->\text { Opening } \\
\text { odds }\end{array}$ & 0.0105 & $\begin{array}{c}\text { hidden } \\
\text { neuron } 21-- \\
>\text { Opening } \\
\text { odds }\end{array}$ & -0.01522 & $\begin{array}{c}\text { hidden neuron } \\
25->\text { Opening } \\
\text { odds }\end{array}$ & $\begin{array}{c}0.02501 \\
5\end{array}$ & $\begin{array}{c}\text { hidden neuron } 27--> \\
\text { Opening odds }\end{array}$ & 0.010704 \\
\hline 82 & $\begin{array}{c}\text { hidden bias } \\
->-> \\
\text { Opening } \\
\text { odds }\end{array}$ & 0.8240 & $\begin{array}{c}\text { hidden } \\
\text { neuron 22 -- } \\
>\text { Opening } \\
\text { odds }\end{array}$ & 0.00098 & $\begin{array}{c}\text { hidden neuron } \\
26->>\text { Opening } \\
\text { odds }\end{array}$ & $\begin{array}{c}0.01035 \\
9\end{array}$ & $\begin{array}{c}\text { hidden bias --> Opening } \\
\text { odds }\end{array}$ & 0.815955 \\
\hline
\end{tabular}

Source: authors (2021)

Figure 1 shows a very similar course of residuals of the RBF networks. Residuals indicate the deviations of the time series models. Residual refers to the difference between the predicted and actual value. Around 26 March 2020, the index was around 50 points in most cases. It follows from Figure 2 that the index fluctuates by 50 points, which is approx. $5 \%$. As the most successful network, the network with the lowest residuals is selected. In this case, it is the network 1.RBF 1-27-1, since it shows the smallest extremes and from all selected networks, its sum of residuals is closes to zero.

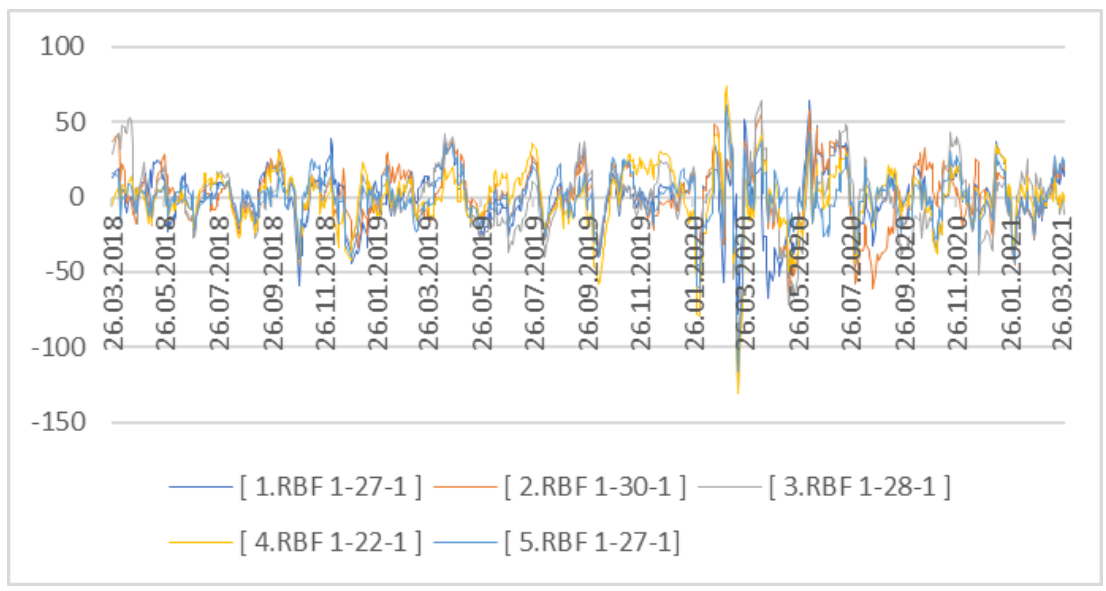

Figure 1. Course of RBF residuals.

Source: authors (2021)

The neural structure with the best results is the network 1.RBF 1-27-1, whose course is presented in Figure 2. As of 31 March 2021, the network reached 1075 points. A slight decrease is projected; therefore, around 31 July 2021, the value might reach 1,073 points, which is 2 points less than in March 2021.

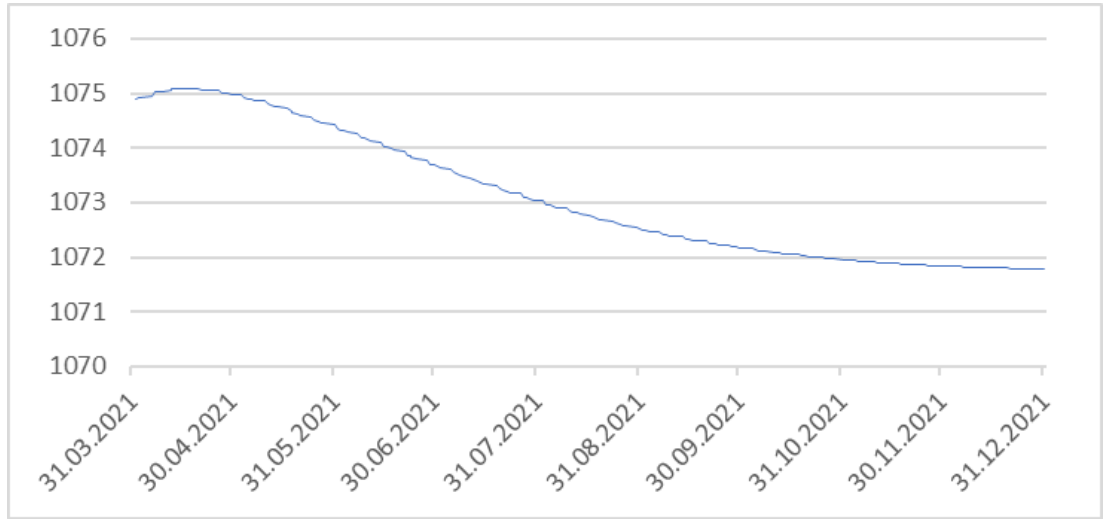

Figure 2. Course of 1. RBF 1-27-1.

Source: authors (2021) 
At the end of 2021, the value shall stabilize at around 1,072 points. This network was selected due to the fact that its sum of residuals is the smallest one of all networks. Moreover, its performance is very high, but the fluctuations in the individual datasets do not show significant differences.

\section{Results and Discussion}

Based on the results obtained, the research questions can be answered as follows:

How did the PX index evolve in the past before the pandemic?

In the past few years, the PX index did not significantly exceed the initial value of 1,000 from the year 1994. Yet, during its existence, the index has undergone a turbulent development mainly around 2008 (Finance v praxi, 2019). In the preceding years, the PX index did not show any long-term trend; all fluctuations were at most in the order of months. This is mainly due to the fact that the enterprises included are very stable. Before the pandemic, the PX index was around its initial value of 1,000 points (Finex.cz, 2021). In 2019, the performance of Prague Stock Exchange measured using the main PX index showed an increase of 129.07 , achieving the value of $1,115.63$, which is a $13 \%$ increase (Finance v praxi, 2019).

The development of the PX index was stable before the COVID-19 pandemic and did not show any enormous fluctuations. The index was around its initial value of 1,000 points.

How is the PX index evolving during the COVID-19 pandemic?

The year 2020 was influenced by the coronavirus pandemic. According to the values of the PX index, which achieved 1027.1 points, Czech shares fell by $7.9 \%$. The development of share prices was similar to the development of foreign shares. The panic over the coronavirus pandemic caused rapid sell-off, with the shares in the Prague Stock Exchange achieving the loss of $38.5 \%$ compared to the situation at the beginning of the year (pse, 2020). The index reached its bottom on 18 March 2020, when it fell by 37\% (690 points). The current values are around 1058 points, which represents an increase by 53\% (fxstreet.cz, 2021).

At the beginning of 2020, the Czech Republic was hit by the COVID-19 pandemic, which also affected the Czech stock market index PX. In March 2020, the index fell to 690 points. Although it has been rising since then, the level of the index is still below the values the index had reached before the coronavirus pandemic.

What is the projected development of the PX index for the year 2021?

Uncertainties concerning further development of the global economy remain high and are related to the pace and effectiveness of the vaccination, which would possibly translate into the demand and thus a faster recovery. For the year 2021, the estimated growth is $2.6 \%$, accelerating to $4.6 \%$ for the year 2022 (ČBA, 2021). Even the possibility that the global stock markets will continue growing beyond the current historical maximum cannot be excluded, since the correlation between the global stock index and global money supply has been very strong since the global financial crisis (Conseq, 2021).

In 2020, the PX index fell to 690 points. However, the Czech stock market index is expected to grow in 2021 and the following years.

\section{Conclusion}

The objective of the paper was to evaluate the development of the PX index between 2018 and 2020 and to predict its future development. The objective was achieved.

It has been found that the PX index was stable in 2018 and 2019, with the value of approx. 1,000 points. However, at the beginning of 2020 , the Czech Republic was hit by the COVID19 pandemic and the Czech stock market index fell significantly. Despite the ongoing restrictions, the PX index is rising again. Although the PX index has not achieved the same 
values as in the period before the pandemic, its constant growth is expected. Each prediction is given by a certain degree of probability; therefore, the authors predicted the future development of the Czech stock market index PX based on the past data. The PX index is expected to rise in 2021 , with its value stabilized around 1,000 points, i.e. as in the period before the global COVID-19 pandemic.

Given the expected rise of the PX index, the volume of investments of enterprises operating in the Czech market is also expected to grow. This means that if enterprises have available funds, they will try to avoid the risk of a decrease in their real value by investing them. These financial funds may be invested in many different ways, i.e. in human resources, new technologies, expansion of production and production facilities, marketing, improvement of logistics, etc. Investments can also be made in ensuring material supplies or modernization of production facilities, or improving working environment for employees.

If an enterprise is stable, it can be expected that early and appropriate investment in its development in any of the above areas brings the enterprises a competitive edge after the global loosening of anti-pandemic restrictions, which may result in its growth and substantial financial profit.- The increase in profits may stem e.g. from the fact that the enterprise has qualified and skilled staff, is able to use new innovative technologies in production, has sufficient production capacity, and is established in the domestic and global market.

\section{Reference}

1. Almehmadi, A. (2021). COVID-19 pandemic data predict the stock market. Computer Systems Science and Engineering, 36(3), 451-460.

2. Al-qudah, A. A., \& Houcine, A. (2021) Stock markets' reaction to COVID-19: Evidence from the six WHO regions. Journal of Economic Studies.

3. Alshammari, A. A., Altarturi, B., Saiti, B., \& Munassar, L. (2020). The impact of exchange rate, oil price and gold price on the Kuwaiti stock market: A wavelet analysis. European Journal of Comparative Economics, 17(1), 31-54.

4. Appiah, M., Frowne, D. Y. I., \& Tetteh, D. (2020). Capital market and financial development on growth: a panel ARDL analysis. Indonesian Capital Market Review, 12(1), 28-41.

5. Bora, D., \& Basistha, D. (2021). The outbreak of COVID-19 pandemic and its impact on stock market volatility: Evidence from a worst-affected economy. Journal of Public Affairs, Article e2623.

6. Burza cenných papírů Praha [Prague Stock Market]. (2021, April). Prague Stock Exchange. https://www.pse.cz/

7. Burza cenných papírů Praha [Prague Stock Market]. (2021, December). Český akciový index PX letos klesl o osm procent na 1027 bodi [The Czech PX stock index fell eight percent this year to 1,027 points]. https://www.pse.cz/novinky/cesky-akciovy-index-pxletos-klesl-o-osm-procent-na-1027-bodu

8. Česká bankovní asociace [Czech Bank association]. (February, 2021). Makroekonomická prognóza ČBA za únor 2021 [CBA macroeconomic forecast for February 2021]. https://cbaonline.cz/makroekonomicka-prognoza-cba-unor-2021

9. Conseq.cz. (2021, March). Vývoj na finančnich trzich [Developments in financial markets]. https://www.conseq.cz/getmedia/c4041bf5-3435-402a-98ad4ea711045b93/markets-report-brezen_1.pdf.aspx

10. Reuse, S., \& Svoboda, M. (2017). Czech PX-TR - derivation of historical data for the performance index and analysis of two trading strategies. (2017). 11th International 
Scientific Conference on Financial Management of Firms and Financial Institutions, Czech republic, 723-731.

11. Dias, R., Pardal, P., Teixeira, N., \& Machová, V. (2020). Financial market integration of ASEAN-5 with China. Littera Scripta, 13(1), 46-63.

12. Finance $v$ praxi [Finance in practice]. (2019, January). Výnosy českých akcií v roce 2019 [Yields on Czech shares in 2019]. https://www.financevpraxi.cz/finance-vynosnostakcii-prazske-burzy-2019

13. Finex.cz. (2021). index $P X$. https://finex.cz/index/px-index/

14. Fxstreet.cz. (2021, February). České akcie zatím nesmazaly ztráty z doby pandemické paniky [Czech shares have not yet erased losses from the time of the pandemic panic]. https://www.fxstreet.cz/ceske-akcie-zatim-nesmazaly-ztraty-z-doby-pandemickepaniky.html

15. Gu, Y., \& Yamashita, N. (2021). An alternating direction method of multipliers with the BFGS update for structured convex quadratic optimization. Computational and Applied Mathematics, 40(3), Article 81.

16. Gubareva, M., \& Chondrogiannis, I. (2020). Capital gains sensitivity of us BBB-rated debt to US treasury market: Markov-Switching Analyses. Complexity, 1-13.

17. Horníková, M. (2003). Modeling the Behavior of Prague Stock Exchange Index. https://econwpa.ub.uni-muenchen.de/econ-wp/em/papers/0304/0304001.pdf

18. Janková, Z. (2019). Comparison of portfolios using markowitz and downside risk theories on the czech stock market. Prague University of Economics and Business.

19. Liu, S., \& Yang, D. (2021). Identification and detection algorithm of electric energy disturbance in microgrid based on wavelet analysis and neural network. EURASIP Journal on Wireless Communications and Networking, 2021(1), Article 27.

20. Lu, B. T., Ma, F., Wang, J. Q., Ding, H., \& Wahab, M. I. M. (2021). Harnessing the decomposed realized measures for volatility forecasting: Evidence from the US stock market. International Review of Economics \& Finance, 72, 672-689.

21. Majerová, J., \& Fernandez, C. (2020). How to make phoenix to arise from the ashes: Brand loyalty as a prospective pillar of branding in tourism after crisis COVID-19. Littera Scripta, 13(2), 49-58.

22. Šuleř, P., Horák, J., \& Krulický, T. (2020). Validation of the prediction of ČEZ stock prices. Littera Scripta, 13(1), 194-210.

23. Vochozka, M., Horák, J., \& Šuleř, P. (2019) Equalizing seasonal time series using artificial neural networks in predicting the Euro-Yuan exchange rate. Journal of Risk and Financial Management, 12(2), Article 76.

24. Vochozka, M., Horák, J., \& Krulický, T. (2020). Innovations in management forecast: Time development of stock prices with neural networks. Marketing and Management of Innovations, 2, 324-339.

25. Yilanci, V., Ozgur, O., \& Gorus, M. S. (2021). Stock prices and economic activity nexus in OECD countries: New evidence from an asymmetric panel Granger causality test in the frequency domain. Financial Innovation, 7(1), Article 11. 